\title{
The frequency, epidemiology and risk factors of bloodstream infections in febrile neutropenic patients with hematologic malignancies
}

\section{Febril nötropenik hastalarda bakteriyemi sıklığı, risk faktörleri ve epidemiyolojisi}

\author{
Cigdem EROL ${ }^{* 1} \square$, Nuran SARI'回, Sahika Zeynep AKI ${ }^{2} \square$, Esin SENOL ${ }^{3} \square$
}

'Baskent University, Faculty of Medicine, Department of Infectious Diseases and Clinical Microbiology, Ankara/TURKEY

2Baskent University, Faculty of Medicine, Department of Hematology, Ankara/TURKEY

${ }^{3}$ Gazi University, Faculty of Medicine, Department of Infectious Diseases and Clinical Microbiology, Ankara/TURKEY

\begin{abstract}
Aim: Bacteremia is considered as the most significant cause of mortality and morbidity in febrile neutropenic patients. The epidemiology and risk factors might differ among institutions and over the time period. The aim of this study is to evaluate the frequency, epidemiology and factors predictive of bacteremia in neutropenic patients in a university hospital in Ankara between November 2007 and November 2008.
\end{abstract}

Material and Methods: 177 febrile neutropenic episodes of 115 patients with hematological malignancies were included in this study. Cases were defined as patients with bloodstream infection and controls were the patients without bloodstream infections. We evaluated the cases and controls for the risk factors, complications and mortality rates. Microorganisms isolated from blood samples and their susceptibility patterns were also analysed.

Results: The prevalence of bacteremia was $61 \%, 42.6 \%$ of them were catheter related and mortality rate was $12.4 \%$. Bloodstream infections are more common in the patients with uncontrolled underlying disease and long term severe neutropenia. Duration of severe neutropenia (neutrophile count $<100 / \mathrm{mm} 3$ ), underlying hematologic malignancy, stem cell transplantation, relapsing or refractory disease, presence of central venous catheter and presence of mucositis were significant predictive factors for bacteremia. Presence of central venous catheter and relapsing or refractory disease were independent risk factors. Candidemia and gram negative bacteremia were significantly associated with higher mortality rates. Gram-positive microorganisms were the most common isolates (76.8\%) with the predominance of coagulase negative staphylococci (63.6\%) with methicillin resistance rate of $64 \%$. The most frequent gram-negative pathogen was Escherichia coli with quinolon resistance rate of $82.1 \%$.

Conclusion: Monitorization for the epidemiology of bacteremia and prediction of significant factors associated with bacteremia in febrile neutropenic patients are considered to be important for the choice of initial antibiotic therapy.

Keywords: Febrile neutropenia; bloodstream infection; risk factors

Corresponding author*: Cigdem EROL, Baskent University, Faculty of Medicine, Department of Infectious Diseases and Clinical Microbiology, Ankara/TURKEY E-mail: ccatalyurekli@yahoo.com

ORCID: 0000-0002-2535-2534

Recevied: 04.10.2021 accepted: 18.11.2021

Doi: 10.18663/tjcl.1002878 


\section{öz}

Amaç: Kan dolaşımı infeksiyonları febril nötropenik hastalarda, ciddi morbidite ve mortalite ile seyretmektedir. Farklı merkezler arasında ve aynı merkezde yıllar içerisinde bakteriyemi epidemiyolojisi ve risk faktörleri değişiklikler göstermektedir. Bu çalışmanın amacı Kasım 2007-Kasım 2008 tarihleri arasında Ankara'da bir üniversite hastanesinde bakteriyemi sıklığını, risk faktörlerini ve epidemiyolojisini belirlemektir.

Gereç ve Yöntemler: Çalışmamızda 115 hematolojik maligniteli hastada gelişen 177 febril nötropeni atağı ve 108 kan dolaşımı enfeksiyonu incelenmiştir. Olgular kan dolaşımı enfeksiyonu gelişen, kontrol grup ise gelişmeyen hasta grubu olarak tanımlanmıştır. Olgular ve kontroller risk faktörleri, komplikasyonlar ve mortalite oranları yönünden karşılaştırılmış; izole edilen mikroorganizmalar ve duyarlılık paternleri incelenmiştir.

Bulgular: Epizodlarının \%61'inde bakteriyemi gelişmiş, bunların \%42.6'sı kateterle ilişkili bulunmuş ve atak ilişkili mortalite hızı \%12.4 saptanmıştır. Altta yatan malignitesi kontrol altında olmayan, uzun süreli derin nötropenisi olanlarda bakteriyemi daha yüksek oranda izlenmiş̧ir. Kök hücre nakil ünitesinde yatmak, altta yatan malignite tanıları, nakil uygulama türünden bağımsız olarak kök hücre nakli varlığı, malignite evresi, santral venöz kateter, mukozit ve ishal varlığı kan dolaşımı enfeksiyonu gelişimi ile ilişkili bulunmuş; altta yatan malignite evresi ve santral venöz kateter varlığı bağımsız risk faktörleri olarak tanımlanmıştır. En sık etkenleri olarak gram-pozitif bakteriler (\%76.8); bunlar içinde de en sık koagülaz negatif stafilokoklar (\%63.6) saptanmıştır. Metisilin direnci koagülaz negatif stafilokoklarda \%64 bulunmuştur. Gram-negatif bakteriler içerisinde ise en sık Escherichia coli izole edilmiştir. Escherichia coli izolatlarında kinolon direnci \%82.1 saptanmıştır.

Sonuç: Sonuç olarak febril nötropenik hastalarda kan dolaşımı enfeksiyonu sıklığının, risk faktörlerinin ve epidemiyolojisinin izlemi, her merkezin kendi empirik tedavi yaklaşımını belirleyebilmesi için önemlidir.

Anahtar kelimeler: Febril nötropeni; kan dolaşımı infeksiyonu; risk faktörleri

\section{Introduction}

In patients with hematological malignancies, invasion of the bone marrow by malignant cells, as well as deep and long-term neutropenia caused by cytotoxic therapy, increase the risk of infection. Fever develops in more than half of the patients one week after aggressive chemotherapy is administered, and fever is frequently the only sign of infection due to an inadequate inflammatory response caused by host defense disorders [1].Because infection mortality and morbidity are high in these patients, even if no infection focus can be detected in the case of fever, empirical antimicrobial therapy should be initiated after blood cultures are obtained following a thorough and rapid physical examination and anamnesis. Bacteremia is the cause of fever in $10-20 \%$ of febrile neutropenic patients. The patient's age, underlying malignancy type and stage, and bone marrow transplantation type are the most important factors that determine the risk of bacteremia, particularly in studies with bone marrow transplant recipients.[1-3]

The type of bacteria that cause bacteremia also varies over the years. While gram-negative agents were isolated more frequently until the early 1990s, the increased use of vascular catheters in the following periods, prophylaxis applications, the agents chosen in the initial empiric treatment were less effective against gram-positive bacteria, mucositis and diarrhea due to chemotherapy had increased the incidence of the gram-positive blood stream infections (BSI). However, in recent studies, an increase in the frequency of gram-negative infections has been observed in both developing and developed countries.[4-6]

This study aimed to determine the frequency of bloodstream infection, microbiological factors, risk factors, and antimicrobial susceptibility in patients with hematological malignancies and bone marrow transplantation at the Gazi University Faculty of Medicine Hematology and Bone Marrow Transplantation Unit.

\section{Materials and Methods}

\section{Patients}

This study included 177 febrile neutropenic episodes in 115 patients with hematological malignancies between November 2007 and November 2008. 'Cases' were defined as patients who had a bloodstream infection, while controls were patients who did not have a bloodstream infection. We compared the risk factors, complications, and mortality rates between cases and controls. Microorganisms isolated from blood samples were also studied, as were their susceptibility patterns. The terms "fever," "neutrope- 
nia," and "severe neutropenia" are defined in the "Guidelines for Diagnosis and Therapy in Febrile Neutropenic Patients."[7]

Bacteremia was defined as the isolation of a pathogenic microorganism from at least one blood sample. Isolation of skin flora elements (coagulase-negative staphylococci, diphteroids, or Bacillus spp.) was accepted as meaningful, as was the presence of an intravascular catheter, fever or hypothermia, trill or hypotension.

Primary bloodstream infection was diagnosed when the causative pathogen isolated from blood culture was not associated with another local infection; secondary bloodstream infection was diagnosed when there was a local infection and the same microorganism was isolated from blood samples and the infection focus. Bacteremia from local catheter infections were also considered secondary bloodstream infections.

The study was approved by Gazi University Faculty of Medicine Ethical Committee.Informed consent of each subject were obtained. The study protocol is in accordance with the Declaration of Helsinki.

\section{Pimary and secondary episodes}

The isolation of a bacterial pathogen from blood samples taken at the start of the fever is recognized as a primary bacteremia episode. The term "secondary bacteremia episode" was used to describe when a different microorganism was isolated from a new blood culture 72 hours later. Isolation of the same microorganism from the same patient, despite the fact that the second sample was taken after 72 hours, was considered one bacteremia episode.

\section{Microbiology}

BacT/Alert automated microbial detection system ((Organon Teknika Corp., Durham, NC) was used for peripheral and catheter blood cultures taken from patients, and for the diagnosis of catheter-related infection, 4-5 cm of catheter segment was rolled across the surface of an agar plate and colony-forming units were counted after overnight incubation. The antimicrobial susceptibility of isolates was determined using the Kirby-Bauer disk diffusion method on Muller-Hington agar in accordance with Clinical and Laboratory Standards Institute (formerly NCCLS) procedures. In addition to traditional microbiological methods, the BBL Crystal Enteric/Non-Fermentative ID and BBL Crystal Gram Positive Identification (Becton Dickinson USA) systems were used to identify isolates. Candida species that form germ tubes were identified as Candida albicans, while others were identified as non-albicans Candida.

\section{Statistical analysis}

SPSS version 17.0 for Windows (IBM Incorporated, Armonk, NY, ABD) was used for data entry and statistical analysis. For analyzing risk factors and complications, we used descriptive statistical methods such as the ki-square test and Fisher's method. Spearmen's correlation method was used for the correlation analysis, and logistic regression analysis was used for the multivariate analysis, with $\mathrm{p}$-values of $<0.05$ considered statistically significant.

\section{Results}

\section{Patients}

In our study male/female ratio was 1/1.9, median age was 44 and mean hospitalization period was $42.2 \pm 27.973$ days. Blood stream infection occurred 61 percent of febrile neutropenic episodes and $42.6 \%$ of these associated with central catheter. Underlying disease of the patients were $59.9 \%$ acute leukemia, $21.5 \%$ lymphoma and $18.8 \%$ other hematological malignancies. Blood stream infection rates were significantly higher presence of uncontrolled underlying disease (70 episodes; $32 / 177$ relaps, $18.1 \%$; 38/177 refractory disease, $21.5 \%)$. Rate of the episodes with BSI without any clinical site was $18.2 \%$ (33/177). We couldn't find any clinical infection site $23.7 \%$ of the episodes. Clinically documented infections and their distribution were showed in table 1.

Table 1. Clinically documented infections and their distribution
Clinical sites of infection n (\%)
Pneumonia 27 (15.3)
Catheter infection 22 (12.4)
Urinary infection $6(3.4)$
Perianal infection 4 (2.2)
Sinopulmonary infection 4 (2.2)
Intraabdominal infection $2(1.1)$
Pneumonia + Catheter infection 13 (7.3)
Pneumonia + Urinary infection 10 (5.7)
Pneumonia + Soft tissue infection 8 (4.6)
Urinary infection + Catheter infection 6 (3.4)
Total 102 (57.6)

There was no significant difference between the patients with BSI and the patients without BSI about age and gender. Mean duration of fever was $10.81 \pm 9.9$ days for cases and $7.42 \pm$ 7.9 for controls and the difference was statistically significant $(p<0.05)$. The difference between cases and controls about duration of severe neutropenia was also statistically significant (17.19 \pm 14.47 days; $12.84 \pm 13.51$ days; $p=0.047$ ). Demographic data for the patients with BSI was compared with the patients without BSI in table 2. 


\begin{tabular}{|c|c|c|c|}
\hline Patients caracteristics & $\begin{array}{l}\text { with BSI n } \\
\qquad \%)^{*}\end{array}$ & $\begin{array}{c}\text { without BSI } \\
\text { n (\%) * }\end{array}$ & $\mathrm{p}$ \\
\hline $\begin{array}{l}\text { Gender } \\
\qquad \begin{array}{l}\text { Female } \\
\text { Male }\end{array}\end{array}$ & $\begin{array}{l}40(56.3) \\
68(64.2)\end{array}$ & $\begin{array}{l}31(43.7) \\
38(35.8)\end{array}$ & 0.296 \\
\hline Age (mean) & $40.8 \pm 14.9$ & $42.78 \pm 16.7$ & 0.415 \\
\hline $\begin{array}{l}\text { Duration of severe } \\
\text { neutropenia(neutrophile } \\
\text { count }<100 / \mathrm{mm} 3 \text { ) }\end{array}$ & $17.19 \pm 14.47$ & $12.84 \pm 13.51$ & 0.047 \\
\hline Duration of fever & $10.81 \pm 9.9$ & $7.42 \pm 7.9$ ) & 0.019 \\
\hline
\end{tabular}

\section{Risk factors}

Risk factors for BSI were hospitalization in stem cell transplantation unit, underlying hematological malignancy, stem cell transplantation (independent from type of transplantation), state of underlying disease, occurrence of CVC, mucositis and having diarrhea $(p<0.05)$. When we made logistic regression analysis only the state of underlying malignancy and occurrence of CVC were found as independent risk factors (the stage of underlying malignancy and occurrence of CVC were independently related with $\mathrm{BSI}$ ). Blood stream infections in patients with relapsing underlying disease were 5.45 times (\%95 Cl; 1.693-17.863) and in the patients with refractory underlying disease were 6.31 times (\%95 Cl; 1.965-20.242) greater than new diagnosed patients. Occurrence of CVC also increased BSI 4.13 times (\%95 Cl; 1.638-10.398). Risk factors for $\mathrm{BSI}$ were showed in table-3.

Blood stream infections were more common in the patients with mucositis and isolated microorganisms were different. Gram-positive microorganisms were $50 \%$, gram negative microorganisms were $16 \%$ and Candida spp. were $6 \%$ and difference was statistically significant $(p=0.021)$. Fluoroquinolone prophylaxis and steroid therapy were increasing the rate of BSI but the difference wasn't statistically significant.

\section{Complications and mortality}

In our study patients with BSI also compared with the patients without BSI in terms of hypotension and intensive care necessity and the difference was statistically significant $(p=0.03$ and $\mathrm{p}=0.014)$. Febril neutropenic episode related mortality rate was $12.4 \%$ (22/177). The difference between the mortality of patients with BSI and without BSI was not significant, but it was found statistically different when the groups were divided. The difference was statistically significant when the groups were separated based on the infectious agents. $(p=0.022)$.
Mortality of secondary BSI was thirteen times higher than primary BSI (95\% Cl; 3.32-51.076). Mortality rates due to BSI types were showed in table 4.

\begin{tabular}{|c|c|c|c|}
\hline Risk factors & $\begin{array}{c}\text { with BSI n } \\
(\%)\end{array}$ & $\begin{array}{c}\text { without BSI } \\
\text { n (\%) }\end{array}$ & $p$ \\
\hline $\begin{array}{l}\text { Department } \\
\text { Hematology clinic } \\
\mathrm{SCT}^{*} \text { unit }\end{array}$ & $\begin{array}{l}59(50.9) \\
49(80.3)\end{array}$ & $\begin{array}{c}7(49.1) \\
12(19.7)\end{array}$ & 0.001 \\
\hline $\begin{array}{l}\text { Underlying hematological } \\
\text { malignancy } \\
\text { Acute leukemia** } \\
\text { Lymphoma*** }^{* *} \\
\text { Others }{ }^{* * *}\end{array}$ & $\begin{array}{l}58(54.7) \\
24(63.2) \\
26(78.8)\end{array}$ & $\begin{array}{l}48(45.3) \\
14(36.8) \\
7(21.2)\end{array}$ & 0.045 \\
\hline $\begin{array}{l}\text { State of underlying malignancy } \\
\text { New diagnosed } \\
\text { Remission } \\
\text { Relaps } \\
\text { Refractory }\end{array}$ & $\begin{array}{l}15(36.6) \\
39(59.1) \\
24(75.0) \\
30(78.9)\end{array}$ & $\begin{array}{l}26(63.4) \\
27(40.9) \\
8(25.0) \\
8(21.1)\end{array}$ & 0.001 \\
\hline $\begin{array}{l}\text { Stem cell transplantation } \\
\text { Allojeneic SCT } \\
\text { Autologous SCT } \\
\text { None }\end{array}$ & $\begin{array}{l}27(81.8) \\
21(77.8) \\
60(51.3)\end{array}$ & $\begin{array}{l}6(18.2) \\
6(22.2) \\
57(48.7)\end{array}$ & 0.001 \\
\hline $\begin{array}{l}\text { Central venous catheter } \\
\text { Yes } \\
\text { No }\end{array}$ & $\begin{array}{l}94(68.6) \\
14(35.0)\end{array}$ & $\begin{array}{l}43(31.4) \\
26(65.0)\end{array}$ & 0.001 \\
\hline $\begin{array}{l}\text { Mucositis } \\
\text { Yes } \\
\text { No }\end{array}$ & $\begin{array}{l}37(74.0) \\
71(55.9)\end{array}$ & $\begin{array}{l}13(26.0) \\
56(44.1)\end{array}$ & 0.026 \\
\hline $\begin{array}{l}\text { Diarrhea } \\
\text { Yes } \\
\text { No }\end{array}$ & $\begin{array}{l}51(71.8) \\
57(53.8)\end{array}$ & $\begin{array}{l}20(28.2) \\
49(46.2)\end{array}$ & 0.016 \\
\hline \multicolumn{4}{|c|}{$\begin{array}{l}\text { *SCT (Stem cell transplantation) } \\
\text { ** ALL ( Acute lymphoblastic leukemia), AML ( Acute myeloblastic } \\
\text { leukemia ), biphenotypical leukemia } \\
\text { *** Hodgkin lymphoma, Non-Hodgkin lymphoma } \\
\text { **** CLL ( Chronic lymphoblastic leukemia), CML ( Chronic myelo- } \\
\text { blastic leukemia), MDS (Myelodysplastic syndrome), MM ( Multiple } \\
\text { myeloma ), AA ( Aplastic anemia) }\end{array}$} \\
\hline
\end{tabular}

\begin{tabular}{|c|c|c|c|c|}
\hline \multicolumn{4}{|c|}{ Table 4. Mortality rates due to BSI types } & \multirow[b]{2}{*}{$\mathrm{p}$} \\
\hline & $\begin{array}{c}\text { Mortality } \\
(+)\end{array}$ & $\begin{array}{c}\text { Mortality } \\
(-)\end{array}$ & Total & \\
\hline Without BSI* (n (\%)) & $5(7.2)$ & $64(92.8)$ & $69(100)$ & 0.022 \\
\hline With $\mathrm{BSI}^{*}(\mathrm{n}(\%))$ & $17(15.7)$ & $91(84.3)$ & & \\
\hline Gram-positive & $8(11.1)$ & $64(88.9)$ & $72(100)$ & \\
\hline Gram-negative & $7(21.9)$ & $25(78.1)$ & $32(100)$ & \\
\hline Candidemia & $2(50)$ & $2(50)$ & $4(100)$ & \\
\hline Primary $\mathrm{BSI}{ }^{*}$ & $5(6.6)$ & $71(93.4)$ & $76(100)$ & 0.001 \\
\hline Secondary BSI* & $12(37.5)$ & $20(62.5)$ & $32(100)$ & \\
\hline
\end{tabular}

\section{Isolates and resistance patterns}

Gram positive microorganisms (76.8\%) were the most common isolates from BSI, followed by gram negatives (2.6\%) and 
Candida spp (1.6\%). Among gram positive bacteria, coagulase negative streptococci were found at the highest rate (63.6\%). Enterococcus species were found in $4.2 \%$ of the samples and Staphylococcus aureus was found in $3 \%$. E.coli was the most commonly isolated gram-negative pathogen (10.3 percent ). This was followed by Klebsiella spp. (4.2\%), Acinetobacter spp(2.1\%), and Pseudomonas spp. (2.1\%).

Methicillin resistance in coagulase-negative staphylococci was found to be $64 \%$ and $25 \%$ in S.aureus, respectively. None of the staphylococcal strains tested positive for glycopeptide or linezolid resistance. In the isolated enterococci, no glycopeptide or linezolid resistance was found. In gram negatives, GSBL positivity was seen $50 \%$ of the E.coli and Klebsiella isolates. Carbapenem susceptibility was found to be 93\% and aminoglycosides susceptibility was $68 \%$. The fluoroquinolone group antibiotics were found to have the most resistance $(82.3 \%)$. The fluoroquinolone group antibiotics were found to have the most resistance (82.3\%). Carbapenem resistance was $25 \%$ in Klebsiella species and flouroquinolone resistance was $42 \%$. Acinetobacter isolates were found to be highly resistant to almost all antibiotics. Two-thirds of the strains were resistant to all antibiotic classes, including carbapenems. In Pseudomonas isolates carbapenem resistance was only $17 \%$.

\section{Discussion}

Bloodstream infections are a serious infectious complication that develops in febrile neutropenic patients and has a high morbidity and mortality rate. Bacteremia is found in $30-40 \%$ of febrile neutropenic patients, and the epidemiology of bacteremia forms the base for empirical treatment selection. Blood stream infections in febrile neutropenic patients were mostly studied in patients with hematological malignancies, particularly those who underwent SCT, and age, malignancy type, and transplantation type were highlighted as risk factors for the development of bacteremia in these series. Although there are fewer data for patients with solid tumors, neutropenia has been identified as the most important risk factor in this group[3].

Blood stream infections was found in $61 \%$ of febrile neutropenic episodes in our study. When compared to other data, our bacteremia rates appear to be high. The reported rates are typically in the $20-30 \%$ range in other studies $[5,8,9]$.

Overall, $40-50 \%$ of FEN episodes are fevers of unknown origin, $20 \%$ are infections which are clinicaly documanted, and 20\% are microbiologicaly documented. While it is defined as an infection, bacteremia can be found in up to $20 \%$ of cases [10]. In our study, no cause of fever was discovered in $23.7 \%$ of the cases. The most common infection (15.3\%) was pneumonia, followed by catheter infection (12.4\%). Six of the nine (5\%) patients who developed sepsis died.

The duration and depth of neutropenia are the most important factors for the development of bloodstream infection. It has been known for many years that it is an important risk factor. Neutrophil level $0-100 / \mathrm{mm} 3$ defined as deep neutropenia, which lasts longer than 10 days in case of severe infection and bacteremia, the frequency is very high[11]. In our study, the mean duration of deep neutropenia 17.19 days in patients with bacteremia and 12.84 days in the control group, and the difference was statistically significant. The mean duration of fever in febrile neutropenic episode at bacteriemic patients was also found to be significantly longer than non bacteriemic patients (10.81 days vs. 7.42 days). BDIs were found to be more commonly associated with prolonged fever and prolonged deep neutropenia.

The underlying type of malignancy and the stage of the underlying disease are important risk factors for the development of bacteremia. Despite previous research indicating that bacteremia is more common in patients with acute leukemia, BSI was found in patients with both non-acute leukemia and non-lymphoma diagnoses in our study[3, 9, 12]. Deeper cellular agents, such as fludarabine, which cause immunodeficiency, have begun to be used; the high rate of autologous SCT in this group, as well as preparatory alkylating agents such as high-dose melphalan, which has a severe mucositis-inducing effect in the regimen, may be the cause of this difference[13, 14]. In our study, the risk of CDI was found to be significantly higher in relapsed or unresponsive patients in both univariate and multivariate analyses (5.45 times in relapsed cases, 6.31 times in unresponsive cases), and these rates are consistent with the literature[12, 15-17]. Uncontrolled underlying disease significantly raises the risk of infection.Chemotherapy should be started as soon as possible, especially if there is bone marrow infiltration, as it will help the patient recover from neutropenia and improve immunosuppression[2].

Many studies have found that SCT is a significant risk factor for the development of BSI[6, 18, 19]. In a study of 264 BSI attacks, it was discovered that SCT increased the risk of bacteremia fivefold[12]. In our study, bloodstream infections were also found to be more common in patients who underwent SCT. When compared to the literature, our rates appear to be extremely high. This increase is thought to be due to the high prevalence of CVC (95\%), mucositis (67\%), and diarrhea 67 
$(82 \%)$ in this group, all of which are defined as risk factors for the development of BSI.

According to the literature, the use of more CVCs today than in previous years increases gram-positive infections, particularly staphylococcal infections. The presence of CVC was found to be an independent risk factor in this study, according to logistic regression analysis, and it was found to increase the development of BDI by 4.13 times. Furthermore, 42.6 percent of the identified BDIs were found to be catheter-related. Catheter type, catheterization time, neutropenia, underlying malignancy, depth of immunosuppression, TPN, catheter location, and catheter care were all identified as risk factors for the development of catheter-related BDI in numerous studies[12, 20, 21].

Another risk factor for $\mathrm{BDI}$ is the presence of mucositis. Grampositive BDIs, particularly infections caused by viridans streptococci, have been reported to be more common in patients with mucositis[4, 10, 22]. In our study, however, BDI increased significantly in patients with mucositis, while streptococcal infection was only 1.9 percent. The reason for this is thought to be the use of antistreptococcal agents in empirical treatment, such as piperacillintazobactam or carbapenems. The presence of diarrhea, like mucositis, has been highlighted in many studies as a risk factor for gram-positive BDI that develops with gastrointestinal flora elements [23, 24]. In our study, patients with diarrhea had a significantly higher rate of BDI.

The presence of BSI is one of the leading causes of increased mortality in febrile neutropenic patients $[9,24,25]$. In our study, it was discovered to be approximately two times higher in patients who developed BSI compared to those who did not. Although it varies according to the factors in the literature, mortality rates have been reported to range between $10 \%$ and $50 \%$. The mortality rates differ depending on the types of isolates. Mortality in BSIs caused by gram-negative agents is higher than in BDls caused by gram-positive agents, and these findings are consistent with our findings.

Many centers have reported that the frequency of gram-negative bacteremia, which had been prevalent in previous years, has shifted in favor of gram-positive bacteremia. [25, 26]. The frequency of BDI caused by gram-positive agents was found to be $76 \%$ in our study, with coagulase-negative staphylococci being the most common among them. However, the situation may vary from center to center or even within the same center over time[27, 28].
Susceptibility patterns, like the distribution of BDI agents, have changed over time. When compared to other studies, the reason why methicillin resistance was low in gram-positive isolates and no vancomycin resistance was observed in our study is thought to be the limited use of glycopeptides[24, 29]. In our study, half of the E.coli isolates from gram-negative bacteria were found to be resistant to 3rd and 4th generation cephalosporins. Resistance to piperacillin-tazobactam has increased by up to $30 \%$, which is thought to be due to its extensive use in empirical therapy. Because sulbactamcefoperazone and carbapenem resistance is detected at less than $10 \%$, these antibiotics are more appropriate for empirical treatment in our center. Resistance was detected at a rate of $25 \%$ in Klebsiella species, even against carbapenems, which are known to be the most sensitive. Acinetobacter isolates are highly resistant to almost all antibiotics. In Pseudomonas species, the highest resistance was detected against cefepime and sulbactam-cefoperazone at a rate of 50\%; carbapenem and aminoglycoside susceptibility was found to be high in general when compared to the literature. Changes in resistance rates have been observed in our center over the years. In our center, increasing resistance has been observed in gramnegative bacteria over the years, especially to 3rd generation cephalosporins, quinolone group antibiotics, and piperacillintazobactam, which is used extensively in empirical treatment. In conclusion, our research shows that, in addition to the duration of neutropenia and the source of bacteremia, the types and resistance patterns of bacteremia agents are important factors influencing mortality. Therefore, the distribution of agents and susceptibility patterns should be monitored on a regular basis over time, both between centers and within the same center. Knowing local data in empirical treatment planning can save the lives of patients who have a high infection mortality rate, such as neutropenic patients.

\section{Declaration of conflict of interest}

The authors received no financial support for the research and/or authorship of this article. There is no conflict of interest.

\section{References}

1. Pennington JE. Fever, neutropenia and malignancy: a clinical syndrome in evolution. Cancer 1977; 39: 1345-9.

2. Akova MÇBN. Nötropenik hastalarda infeksiyonlar. In: Topçu AW SG, Doğanay M, editor. Enfeksiyon Hastalıkları ve Mikrobiyolojisi: Nobel Tıp Kitabevleri; 2008. p. 641-50. 
3. Toussaint E, Bahel-Ball E, Vekemans M, Georgala A, Al-Hakak L, Paesmans $\mathrm{M}$, et al. Causes of fever in cancer patients (prospective study over 477 episodes). Supportive care in cancer : official journal of the Multinational Association of Supportive Care in Cancer 2006; 14: 763-9.

4. Blijlevens NM, Donnelly JP, de Pauw BE. Empirical therapy of febrile neutropenic patients with mucositis: challenge of riskbased therapy. Clinical microbiology and infection : the official publication of the European Society of Clinical Microbiology and Infectious Diseases 2001; 7: 47-52.

5. Viscoli C, Cometta A, Kern WV et al. Piperacillin-tazobactam monotherapy in high-risk febrile and neutropenic cancer patients. Clinical microbiology and infection : the official publication of the European Society of Clinical Microbiology and Infectious Diseases 2006; 12: 212-6.

6. Oliveira AL, de Souza M, Carvalho-Dias VM et al. Epidemiology of bacteremia and factors associated with multi-drug-resistant gram-negative bacteremia in hematopoietic stem cell transplant recipients. Bone marrow transplantation. 2007;39:775-81.

7. Febril Nötropeni Çalışma Grubu. Febril Nötropenik Hastalarda Tanı ve Tedavi Kılavuzu. Flora 2004; 9: 5-28.

8. Büyüktuna $S A$, Saba R, Gözel MG et al. Secondary infections after cytotoxic chemotherapy in patient with hematological malignancies. Journal of infection in developing countries 2017; 11: 521-6.

9. Nørgaard M, Larsson H, Pedersen G, Schønheyder HC, Sørensen HT. Risk of bacteraemia and mortality in patients with haematological malignancies. Clinical microbiology and infection : the official publication of the European Society of Clinical Microbiology and Infectious Diseases 2006; 12: 217-23.

10. Marron A, Carratalà J, González-Barca E, Fernández-Sevilla A, Alcaide F, Gudiol F. Serious complications of bacteremia caused by Viridans streptococci in neutropenic patients with cancer. Clinical infectious diseases : an official publication of the Infectious Diseases Society of America 2000; 31: 1126-30.

11. Bodey GP, Buckley M, Sathe YS, Freireich EJ. Quantitative relationships between circulating leukocytes and infection in patients with acute leukemia. Annals of internal medicine 1966; 64: 328-40.

12. Velasco E, Thuler LC, Martins CA, Dias LM, Gonçalves VM. Risk factors for bloodstream infections at a cancer center. European journal of clinical microbiology \& infectious diseases : official publication of the European Society of Clinical Microbiology 1998; 17: 587-90.
13. Vento S, Cainelli F. Infections in patients with cancer undergoing chemotherapy: aetiology, prevention, and treatment. The Lancet Oncology 2003; 4: 595-604.

14. Niscola P, Romani C, Cupelli L, Scaramucci L, Tendas A, Dentamaro $T$, et al. Mucositis in patients with hematologic malignancies: an overview. Haematologica 2007; 92: 222-31.

15. Talcott JA, Siegel RD, Finberg R, Goldman L. Risk assessment in cancer patients with fever and neutropenia: a prospective, twocenter validation of a prediction rule. Journal of clinical oncology : official journal of the American Society of Clinical Oncology 1992; 10: 316-22.

16. Elting LS, Rubenstein EB, Rolston KV, Bodey GP. Outcomes of bacteremia in patients with cancer and neutropenia: observations from two decades of epidemiological and clinical trials. Clinical infectious diseases : an official publication of the Infectious Diseases Society of America 1997; 25: 247-59.

17. Britt MR, Schleupner CJ, Matsumiya S. Severity of underlying disease as a predictor of nosocomial infection. Utility in the control of nosocomial infection. Jama 1978; 239: 1047-51.

18. Hamalainen S, Kuittinen T, Matinlauri I, Nousiainen T, Koivula I, Jantunen E. Severe sepsis in autologous stem cell transplant recipients: microbiological aetiology, risk factors and outcome. Scandinavian journal of infectious diseases 2009; 41: 14-20.

19. Collin BA, Leather $\mathrm{HL}$, Wingard JR, Ramphal R. Evolution, incidence, and susceptibility of bacterial bloodstream isolates from 519 bone marrow transplant patients. Clinical infectious diseases : an official publication of the Infectious Diseases Society of America 2001; 33: 947-53.

20. Worth LJ, Slavin MA, Brown GV, Black J. Catheter-related bloodstream infections in hematology: time for standardized surveillance? Cancer 2007; 109: 1215-26.

21. Howell PB, Walters PE, Donowitz GR, Farr BM. Risk factors for infection of adult patients with cancer who have tunnelled central venous catheters. Cancer 1995; 75: 1367-75.

22. Offidani M, Corvatta L, Olivieri A et al. Infectious complications after autologous peripheral blood progenitor cell transplantation followed by G-CSF. Bone marrow transplantation 1999; 24: 1079-87.

23. Cordonnier C, Buzyn A, Leverger $G$ et al. Epidemiology and risk factors for gram-positive coccal infections in neutropenia: toward a more targeted antibiotic strategy. Clinical infectious diseases : an official publication of the Infectious Diseases Society of America 2003; 36: 149-58. 
24. Velasco $E$, Byington $R$, Martins CA, Schirmer M, Dias LM, Gonçalves VM. Prospective evaluation of the epidemiology, microbiology, and outcome of bloodstream infections in hematologic patients in a single cancer center. European journal of clinical microbiology \& infectious diseases : official publication of the European Society of Clinical Microbiology 2003; 22: 137-43.

25. Klastersky J, Ameye L, Maertens J et al. Bacteraemia in febrile neutropenic cancer patients. International journal of antimicrobial agents 2007; 30: 51-9.

26. Almyroudis NG, Fuller A, Jakubowski A et al. Pre- and post-engraftment bloodstream infection rates and associated mortality in allogeneic hematopoietic stem cell transplant recipients. Transplant infectious disease : an official journal of the Transplantation Society 2005; 7: 11-7.

27. Wisplinghoff H, Reinert RR, Cornely O, Seifert H. Molecular relationships and antimicrobial susceptibilities of viridans group streptococci isolated from blood of neutropenic cancer patients. Journal of clinical microbiology 1999; 37: 1876-80.
28. Paul M, Gafter-Gvili A, Leibovici L et al. The epidemiology of bacteremia with febrile neutropenia: experience from a single center, 1988-2004. The Israel Medical Association journal : IMAJ. 2007; 9: 424-9.

29. Rolston KV, Yadegarynia D, Kontoyiannis DP, Raad, II, Ho DH. The spectrum of Gram-positive bloodstream infections in patients with hematologic malignancies, and the in vitro activity of various quinolones against Gram-positive bacteria isolated from cancer patients. International journal of infectious diseases : IJID: official publication of the International Society for Infectious Diseases 2006; 10: 223-30. 